紹介した。

発言九大整形天坚民和

本島教授が宿題で本症のレ線所見の多様性を指摘し ていられる. 又手術は滕盖健下の free の骨片は摘出 するがよい，自然治瘾があるので手術効果の判定に注 意を要す.

追加長大整形 永 井三 郎

1）私達最近 10 年間ボールングをやつた OsgoodSchlatter 氏病の遠隔成績をしらべてみた。 その成績 は決して悪いあのではない，患者が一定期間辛棒でき るなら手術の適応範囲は少いのではないかと存ずる.

2） 1956 年 Thomson が唯今厚生年金の方が報告 されたと同じ様な手術法を発表した際, Ferguson が
発言しているが成長期を待てば痛みもとれ，その変形 もそれ程目立たなくなると申している。

質問 長崎原爆病院 三 原 茂

(1) Osgood-Schlatter 氏病は放置していたらよく ならないか.

(2) 又，放置していたら変形は增強するあのである か,

答厚生年金 浦 田固志

Osgood-Schlatter 氏病の治療で手術的療法をしな くても年月がたてば症状が軽快するものが多い.

但し疼痛が強くて日常生活に不自由を来す様なもの に手術をすすめるのがよい，手術をする限りは確実に 遊離骨折を削除する.

\title{
最近の骨関節結核の傾向に就て
}

九州大学整形外科教室 (主任 天児民和教授)

橘

寬

\section{An Observation on Tuberculosis of Bone and Joint}

By

\author{
H. Tachibana \\ Department of Orthopedic Surgery, \\ Faculty of Medicine, Kyushu University
}

結核は戦争中, 或は戦争後など生活状態の覀い時期 に蔓延する疾患の一つとして代表的なあのの一つであ ることは周知の通りである.しかし第二次大戦後既に 18 年経過して一般の生活様式む大いに改善され, 又と の間各種抗生物質の普及を初めとし, 治療法にも進歩 の著しい今日, 結核一般に就ていへば死亡率の著明な 低下など，その様相が大きく変つたといはれてるる。 骨関節結核に就ても患者数の著しい減少を初め, いく つかの変化がみられるので, それらの一端に就て調査 結果を報告する.

当教室では, 今次戦争中より戦後にかけての骨関節 絬核に就て，宮崎による昭和 12 年より 21 年までの 10 年間, 及び岩切等による昭和 21 年より 30 年に至る 10 年間の統計があるので私は昭和 31 年以降のものに就 てとれらと比較しながら述べたいと思ふ。

調査対象は昭和 31 年初より昭和 37 年末までの 7 年
間に当教室外来を訪れた患者 31513 名中の骨関節結核 患者724名で, てれらの外来病歴に就て調査した.

1）先づ患者数に就て述べる. 昭和 12 年より 21 年 に至る 10 年間では外来患者総数 30807 名に対して骨 関節結核患者は 2853 名, 即ち $9.2 \%$ \%あり, 又との 10 年間を前後の二期に分けて見ると, 後半つまり太平洋 戦争の激化して来た昭和 17 年より終戦直後の 21 年ま での 5 年間では, 前半に比し結核患者が実数で 109 名, 比率にして $1.2 \%$ 増加してるる. この様な状態は昭和 24 年まで続き, 24 年から結核患者の比率の低下 が著 明になつて来たが，乙れは外来患者数の増加によるも ので, 結核患者の実数は 21 年から 28 年まで殆ど同数 である.結核患者がその比率のみでなく実数に於ても 著明に減少し始めたのは昭和 30 年からである, との減 少の傾向はその後現在まで続き, 35 年以降は患者比 率は遂に $1 \%$ 台にまで低下してるる。乙れは戦争中乃 
至戦後数年間の約 $10 \%$ に比し著しい減少であるが, 更 に大正年間の教室に於ける骨関節結核患者比率 $59.9 \%$ と比較すると驚くべき減り方であり，との間患者の減 少のみでなく，他の整形外科的疾患注対する一般の認 識が深まつたてとなどの影響を考慮に入れてもなほ隔 世の感がある（図1）.

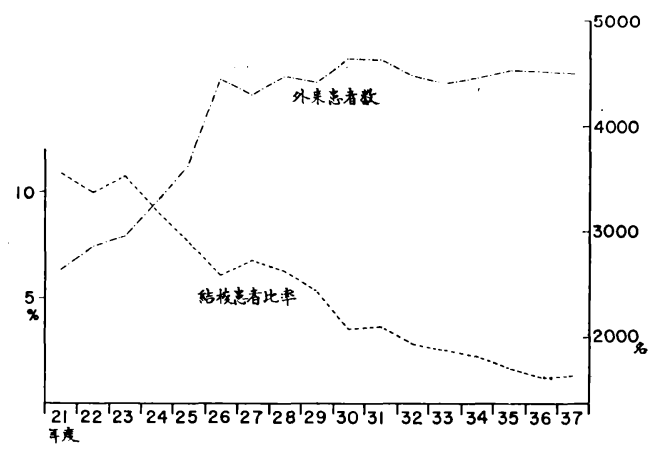

図1 外来患者数及び結核患者の比率の年次推移

2）次滑関節結核を䍜患部位別にみると，昭和 31 年以降は脊椎カリエスが $50.5 \%$ と約半数を占めてを り，乙れは 12 年から 21 年までの $53.6 \% ， 21$ 年から 30 年までの $52.5 \%$ に対し稍々減少してるるが, 大差は ない。しかし，てれも大正年間の脊椎カリエスの頻度 $93.2 \%$ と較べると著しい相違である.

以下股関節, 滕関節, 足関節という順序は何れの統 計でも変らず,その他のものに就ても 30 年までの統計 と較べて, 夫々の頻度, 順位など著明な変化は認めら れない(図2).

\section{部位别頻度}
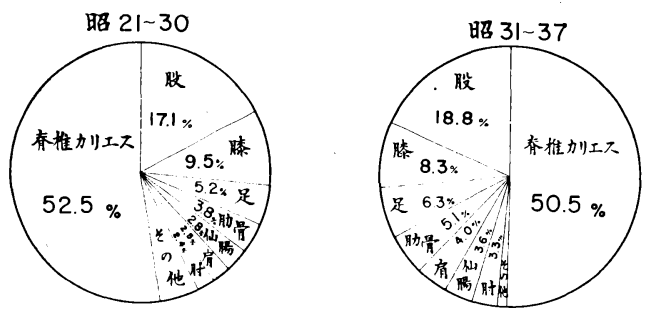

図 2

3）年令別発生頻度に関しては先輩諸氏の例飞做 ひ，骨関節結核に明らかに関係があると思はれる何ら 加の自覚的, 或は他覚的症状を現はした時期をとり, これを発病年令として年令別頻度を出した。
骨関節結核全体に就てみると, 最屯多いのは 1 才か ら 5 才までであり, 次で 21 才から 25 才までで, こと に二つの大きなピークを作るととは前述の二つの統計 と一致してるる. しかし， 30 年までと 31 年以降とを 比較すると, 後者では両ピーク共その高さを減じ, 特 に 5 才以下に於てそれが著しく, 又 26 才以上では減少 の勾配が綬やかで，しかも上方凸の曲線となり，30才 乃至 40 才の壮年者の結核が相対的に増加したととを 示し, 更に 51 才以上の高年者も増加の傾向を示してい る(図 3)

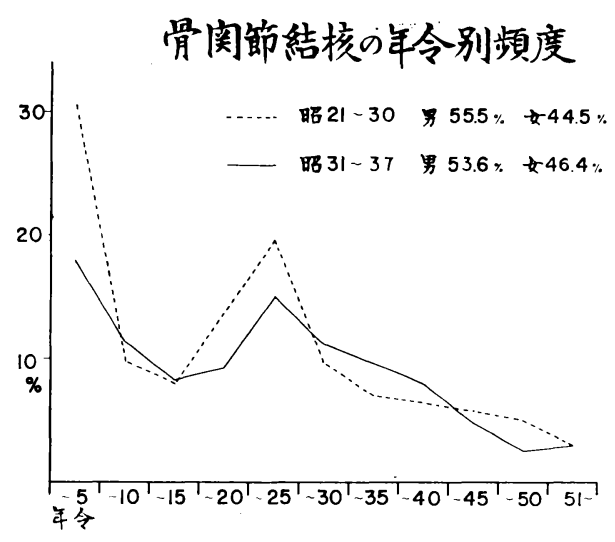

図 3

てれを各疾患別にしてみると, 骨関節結核の約半数 を占める䩀椎カリエスでは，結核全体のグラフ(図 3) に略々平行した傾向を示している. しかし関節結核の 代表的なむの之して股関節及び滕関節結核に就てみる と大分趣が異り，何れも 5 才以下が压倒的に多く，以 後年令と共汇急激に減少している.乙れは 30 年までの 統計であ大体同様であるが, 唯ここであ 5 才以下のピ 一クは稍々低下し, 相対的に成人の発病が増加する傾 向がみられる（図4).

又, 肋膜周囲膿瘍之仙腸関節結核に就てみると, 四 肢の結核とは対照的で，何れも 20 才から 45 才までの 成人に多発してをり, 5 才以下の患者は皆無であつた.

4）性別では骨関節結核全体で男 $53.6 \%$,女 $46.1 \%$ 之男子に稍々多く各疾患別にみても従来の統計と殆ど 変りはない（図3).

5）前病歴の中, 特に結核性疶患と外傷とを取り上 げてみると, 15 才以上の脊椎カリエスで肺浸潤及び 助膜炎の既往歴を有する者の多いととが目立ち以前の 統計でも同様の傾向がみられるが唯肋膜炎の既往歴を 


\section{股闲柿·滕闺篎結㧡の年令别频度}

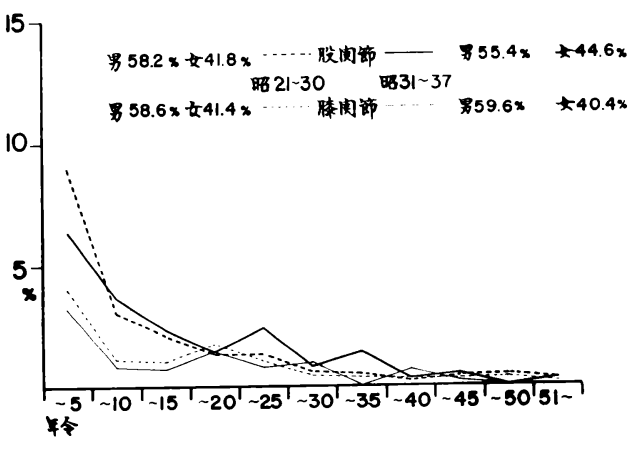

図 4

有する者が以前よりは減少してるる．

6）家族歴に就ては，家族又は同居人に結核性疾患 のある者を年令別にみると，全般的に以前に比して減 少してをり, 結核患者全般の減少につれて, 同居人に 患者を有する率す低くなつて来た事は当然であるが， 唯 5 才以下の幼児で同居人に結核患者を有する者の比 率は約 $30 \%$, 以前の統計と較へて殆ど低下してをら ず, 家庭内での感染が現在であなほ強く影響してるる と考へられ，との点特に注目すべきだと思う.

尚, 前述の様に脊椎カリエスは骨関節結核の半数を 占めて居るので, てれに就て少し補足すると, 先づ罹 患椎体別の頻度は腰椎之胸椎とが同率の $47.1 \%$ である が, 胸椎を上中下の三つに区分すると図 5 の様に腰椎 の次は胸椎下部, 次で胸椎中部, 上部, 仙椎, 頸椎の 順となる. 30 年までと大体の傾向は同じであるが, 頸 椎及び, 胸椎上部が減少し, 胸椎中部, 及び仙椎が幾 分増加してるる. 更に椎体個々に就てみると頸椎及び 胸椎では下位になる程罹患率が高くなつてるるが, 腰 椎では第 2 , 第 4 , 第 5 , 第 3 腰椎の順となつてるる.

椎体高位別の発生頻度を更に年令層別にみると, 10 才以下の者では頸椎以下全般に亘つて発病し, 特に頸

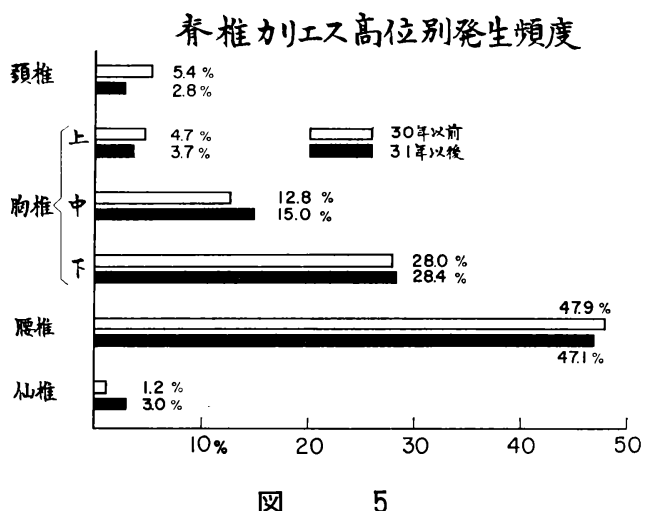

図 5

椎及び胸椎上部のカリエスが, 他の年令層よりも多発 する傾向がみられ，20才より 40 才までの成人では胸 椎下部から腰椎にかけての発病が圧倒的に多くなつて ある。

脊椎カリエスの膿瘍及び瘦孔に就ては, 昭和 21 年に はこれを有する患者が $52.3 \%$ \%すつたが, その後次第 に減少し, 30 年には $32.3 \%$ となり, 31 年以後は大体 $25 \%$ 前後に減つて来てるる, てれと共に前述の通り患 者の絶対数の減少も著しく, ての為我々は成書に記載 のある様な膿瘍を診る機会は極めて少くなつてるる.

以上昭和 31 年以降の 7 年間に教室外来を訪れた骨 関節結核患者に就て二三調査した結果を報告した。

\section{文献}

1）宮崎正晴: 九大神中整形外科教室講演集. 昭和 21 ２3 年.

2) 岩切清文 - 星野 致 - 藤川輔一：九州大学結核研 究所紀要. 第 3 巻, 第 1 号, 30 , 昭 31 .

3) 島田信勝: 日整会誌. 第 8 巻, 293 , 昭 8 .

4) 内藤三郎 - 別所正恭：日外会誌. 第 23 回, 710, 大正 10 . 